\title{
W 15-1
}

\section{食細胞 NADPH オキシダーゼ活性化の分子機構}

○住本英樹, 赤崎卓, 古賀博文, 吾鄉哲朗, 武谷立, 塩瀬明, 信久幾夫, 栗林太 (九大・院医系・分子病態学)

食細胞 NADPHオキシダーゼは、微生物の貣食時等に活性化され、高殺菌能をもつ活性 酸素の前駆物質スーパーオキシドを生成する酵素系であり、その酵素本体は細胞膜に存在 するシトクロム $b_{558}\left(\mathrm{gp} 91^{\text {phox }}\right.$ とp22 $22^{\text {phox }}$ の 2 つのサブュニットから成る)である。オキシダー ゼは細胞休止時には不活性型であり、その活性化には、特異的アダプター蛋白質 (p47 $7^{\text {phox }}$ と $\mathrm{p} 67^{\text {phox }}$ ) と低分子量 $\mathrm{G}$ 蛋白質 Rac が刺激依存性に細胞質から細胞膜に移行してシトクロ $厶 b_{558}$ と相互作用する必要がある。私共は、p47 $7^{\text {phx }}$ とRac が同時に「活性化型」になることが、

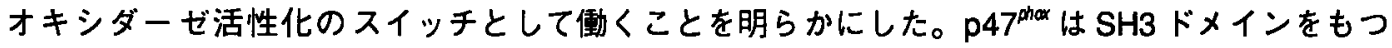
蛋白質であるが、このSH3ドメインは分子内結合により mask されている。p47 は、構造変化によって SH3 ドメインが unmaskされており、そのため SH3 ドメインを介して p22 phox と結合できる(この結合は NADPH オキシダーゼ活性化に必須である)。このような $047^{\text {phox }}$ の活性化は、p47 $7^{\text {phax } C}$ 末領域の 3 つのセリン残基 (S303, S304, S328) のリン酸化により誘道され る。更に、アラキドン酸はリン酸化と協同的に p47 妿ax 構造変化を引き起こしオキシダーゼを活 性化する。一方、FMLP 等で刺激された好中球では、Rac は、PI3K 依存性に活性化されて GTP 結合型になり、p67 $7^{\text {phx }}$ の N 末領域に存在するTPRドメインに結合してオキシダーゼを活性化する。

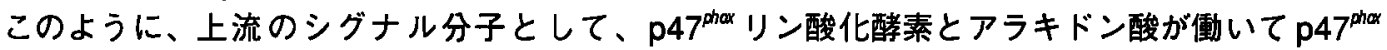
を、PI3Kが働いて Racをそれぞれ活性化し、両者によってオキシダーゼが活性化される。

\section{W 15-2}

慢性肉芽腫症患者の臨床的解析

○布井博幸、石橋史成、水上智之、レジナ・マリア

熊本大学医学部付属病院小児科

慢性肉芽腫症(CGD) は食細胞のスーパーオキシド $\left(\mathrm{O}_{2}{ }^{-}\right)$産生能の欠損により乳児期よ り重症細菌感染を繰り返す遺伝性疾患である。 $\mathrm{O}_{2}$-は二つの細胞膜蛋白質 (gp91-,p22phox)と三つの細胞質蛋白質(p47-,p67-phox 及び racp21)が活性化に伴い、細胞膜で電子 伝達系を形成し、酸素に電子を渡すことにより産生される。このいずれかの phox 蛋白 質の欠損か機能異常が CGD の病因である。治療としては、ST 合丳や IFN-ץの予防投 与が有効な方法として報告され、さらに、骨䯣移植と遺伝子治療の研究が進んでいる。

我々は、これまで日本における患者の QOL を含めた基礎的統計、遺伝子解析や遺伝 子治療の基礎的研究を行ってきた。この一連の解析の中で、わずかながら $\mathrm{O}_{2}{ }^{-}$産生能 を残す 2 家系 3 名の X-CGD 患者が gp91-phoxのスプライス変異であることを明らかに した。これらの患者は IFN- $\gamma$ 投与後 2-3 週目に明らかな好中球 $\mathrm{O}_{2}$ 産生能の上昇と gp91-phox mRNA のスプライスパターンの変化を示し、僅かながら正常な gp91-phoxを 合成していた。

これらのことから、IFN- $\gamma$ は骨髄造血幹細胞で gp91-phox 遺伝子のスプライス機構 に何らかの作用を及ぼし、2-3 週後にその効果が現れたものと考えている。この他、 種々の興味ある症例が解析されているので遺伝子解析の結果と合わせて報告する。 


\section{W 15-3}

サイトカインによるヒト好中球機能活性化とMAP キナーゼ

○鈴木賢一、北川誠一

(大阪市立大学医学部・第二生理学)

ヒト好中球機能は、G-CSF、GM-CSF、TNF $\alpha$ および IL-1 $\beta$ により活性化される。これら サイトカインによる MAP キナーぜ（MAPK）サブタイプの活性化とその意義について検索 した。G-CSFにより MEK-ERK 系が選択的に活性化され、GM-CSF により MEK-ERK 系が 強く MKK3/6-p38 MAPK系が弱く、TNF により MKK3/6-p38 系が強く MEK-ERK系が弱く

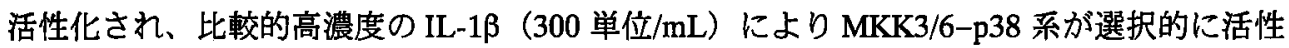
化された。JNK1/2 はいずれのサイトカインによっても活性化されなかった。GM-CSF およ びTNF $\alpha$ による好中球の活性酸素産生、およびIL-1 1 による CD11b の upregulation には、p38 が関与していることが明らかになった。G-CSF は好中球寿命を延長させる作用があったが、 IL-1 $\beta$ にはその作用はなく、p38は好中球の apoptosisには関与していなかった。一方、低濃

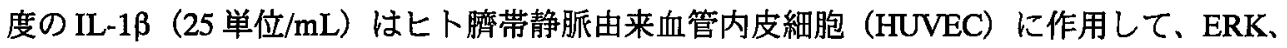
p38 および JNK を活性化した。IL-1 $\beta$ に対する好中球と HUVEC の感受性の違いは、IL-1 $\beta$ 受容体の発現の相違（好中球は主として II 型、HUVEC はI 型のみを発現）によると考えら れ、炎症局所に集積した好中球は、II 型受容体（decoy receptor）を介して IL-1ßをトラッ プし、過度の炎症進行を抑える役割も果たしていると考えられた。

\section{W 15-4}

サイトカインによる好中球の活性化とアクチンの再構築

○忽那晴央, 石井正光

(大阪市立大学医学部・皮膚科学)

GM-C S F およびTN F $\alpha$ は、ヒト好中球に作用してスーパーオキシド産生を誘導す る。この作用は、サイトカラシンBにより完全に阻害される。このことはサイトカインに よりアクチンの再構築が誘導され、アクチンの再構築がサイトカインによる好中球活性化 に重要な役割を果たしていることを示唆している。今回、サイトカイン刺激によるヒト好 中球アクチンの再構筑をF I T Cファロイジンをプローブとして、フローサイトメーター 及び共焦点レーザー顕微鏡で解析した。走化性因子（FMLP）は好中球アクチンの重合 を誘導した。GM-C S F およびT N F $\alpha$ は、アクチンの脱重合を誘導した。アクチンの 脱重合はサイトカインの濃度依存性であり、サイトカイン刺激 10 分後に最大となり、3 0 分後には、静止時の状態に復した。これらのサイトカインによるアクチンの脱重合は、 サイトカラシン B、MEK阻害剤（PD９８０５９）、および p 38 M A P K 阻害剤（S B 2003580 ) により阻害された。また、GM-C S F またはT N F $\alpha$ 刺激による好中 球のスーパーオキシド産生もM E Kおよび p $38 \mathrm{MAPK}$ 阻害剤により阻害された。これ らの結果は、 $\mathrm{GM}$ - C S F およびT N F $\alpha$ によるアクチンの脱重合は、E R Kおよび p 3 $8 \mathrm{MAPK}$ ～Kより制御されており、好中球のスーパーオキシド産生の活性化に重要な役割 を果たしていることを示している。 


\section{W 15-5}

好中球の細胞運動における細胞骨格とシグナル伝達系

$\mathrm{O}^{1}$ 大原尚子、 ${ }^{1}$ 高橋 淳、 ${ }^{1}$ 内山 卓、 ${ }^{2}$ 月田早智子、 ${ }^{2}$ 世田昌孝、

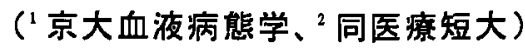

【目的】好中球の細胞運動における ERM(Ezrin/ Radixin/Moesin)のリ酸化・脱リ酸化がど のように時間的空間的に制御されているかを検討した，さらに脱リ酸化䤃素阻害郕および ROCK(Rho-associated coiled-coil forming kinase)阻害剤の影響についても検討した.

【方法】七卜末梢血より好中球を分離した．好中球の運動は FMLP、および GM-CSF により

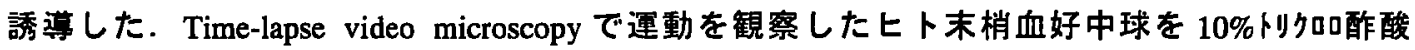
で固定した後、リン酸化 ERM への特異的抗体を用いて好中球の活性化 ERM の動態を検討 した。さらに脱リン酸化酵素阻害剤; Calyculin A、ROCK 阻害剂; Y 27632 による好中球の形 態と運動、ERMの局在の変化について検討した.

【結果と考察】無刺激の好中球では、リ酸化 ERM は細胞辺縁全周性に認めた。 FMLP、 GM-CSFにて運動を誘導した好中球では後部の uropodに局在した. Caluculin A 100ng/ml に より脱リン酸化を抑制すると前方への突出は起こるが、尾部が基質から雖れず、移動でき なくなった。免度染色では尾部にリ酸化 ERM の強い集合を認めた。好中球運動における 脱リ酸化醉素の重要性が示唆された。また、細胞運動に重要な Y27632(100ug/ml)で処理後 fMLP で刺激すると細胞の異常な伸展を認めた. Rhoによって活性化される ROCK が張力、 接着を制御して好中球の形態維持および尾部の脱離に関与していると考えられた。 
W 16-1

SLE末梢血リンパ球における内在性レトロウイルス遺伝子の発現の検討

○小笠原均 1 , 金子礼志 1 , 菱川隆史 1 , 関川熶2, 丸山直記 3 , 山本直樹 4 , 橋本博史 1

( 1 順天堂大学・膠原病内科, 2 同・伊豆長岡病院・内科, 3 東京都老人総合研究所

- 分子病理, 4 東京医科歯科大学・微生物）

〔目的〕自己免疫疾患モデルマウスの病態形成に内在性レトロウイルスが関与している 報告がある。しかしヒトの全身性エリテマトーデス(SLE)の病態形成においてヒト内在性 レトロウイルス(HERV)が関与している報告は少ない。我々はSLEを含めた膠原病患者血清 中にHERV遺伝子産物に対する抗体活性を認めることを本学会において述べてきた。今回、 SLEリンパ球中のHERV 遺伝子のmRNA発現をRT-PCRにて確認し、さらにTaqMan PCR 法により定量化を行い、同疾患の治療に伴う発現量の変化を検討した。〔方法〕SLEの末 梢血リンパ球よりmRNAを分離し、HERV clone 4- 1のgag部分の塩基配列より作成した primer を用いてRT-PCR 施行し、これにより得られたPCR 産物の塩基配列を直接塩基 配列決定法にて解析した。また、TaqMan ABI prism 7700を用い、mRNA発現量の定 量化を行った。【結果〕1.SLEでは健常人と比較し、HERV clone 4-1 gag遺伝子の mRNA発現量が高値をしめた。2. 未治療SLE症例において、治療前後のgag 遺伝子の mRNA発現量を検討した結果、ステロイド治療によりその低下をみとめた。〔結語】 HERV 遺伝子は健常人DNAにも存在する。しかし、mRNA 発現量を定量化してみると、明 らかにSLE患者リンパ球において強く発現しており、同疾患の病態形成にHERV遺伝子の発 現調節機構が関与している可能性が考えられた。

W 16-2

S L Eなどの病態におよばすサイトメカロウイルス感染の臨床的検討

○林 健志 ${ }^{1}$ 、関川 巖 ${ }^{1}$ 、飯田 昇 ${ }^{1}$ 、橋本博史 ${ }^{1}$ 、富野康日己 ${ }^{3}$

( 1 順天堂大学 順天堂伊豆長同病院、2 同 膠原病内科、 3 同 腎臟内科)

〔目的〕ウイルス感染症は、種々の免疫異常を誘導するが、S L Eなどの病態にサイトメ カロウイルス感染が重要な役割を果たしたと考えられるいくつかの症例を経験したのでこ れらをまとめ報告する。

〔症例〕症例 1 は、2 1 歳女性で、不明熱、皮疹にて膠原病疑われるも自然軽快し、血清 所見などより翏原病は否定的であった。その後、発熱、蛋白尿など出現し、抗D N A 抗体 陽性などの所見よりS L E と診断された。症例 2 は、3 3 歳女性で、以前よりS L Eの診 断にて加療中であったが発熱とともに急激な血小板減少を認めた。症例 3 は、4 1 歳女性 で、MC T D、シェーグレン症候群にて経過観察中であったが、発熱と全身の紅斑の出現 をみている。以上の3例は、いずれも発症時に I g Mクラスーサイトメカロウイルス抗体 価が上昇しており、ウイルス抗原（P C R 法）の同定がされた。ステロイド加療にて良好 な経過をたどっている。

[結語】症例 1 は、サイトメガロウイルス感染を契機にS L E が発症したもので、症例 2 および 3は、同感染症が、その病㦔の増悪に関与したと考えられる症例である。報告例を 通して、S L Eなどの膠原病の発症、増悪時にサイトメガロウイルス感染に注目すること の必要性が示唆された。 


\section{W 16-3}

全身性エリテマトーデスの病因に関わるレトロウイルスの可能性

〜HIV研究で得られた知見をもとに〜

$\bigcirc$ 金子礼志 ${ }^{1}$, 小笠原 均 1 , 内藤俊夫 ${ }^{2}$, 菱川隆史 ${ }^{1}$, 関川 镢 ${ }^{3}$, 橋本博史 ${ }^{1}$

(1 順天堂大学 ·膠原病内科, ${ }^{2}$ 同 ·総合診療内科, ${ }^{3}$ 同 - 伊豆長岡病院 - 内科)

〔目的〕全身性エリテマトーデス(SLE)の病因については従来よりレトロウイルスの関 与が示崚される研究報告があるが、依然明快な解答は得られていない。本演題においては、 SLEの発症に関わる環境因子の中で、とりわけレトロウイルス感染の関与の可能性につい て我々の研究をもとに考察したい。〔方法〕1.HIV 外被糖蛋白gp120を添加した健常人末 梢血単核球(PBMC)におけるサイトカイン産生能、活性化マーカー(HLA-DP)の発現を検 討した。2.HIV研究で注目された各種ケモカインとIL-16について、SLE患者血清中にお ける值をELISAにて測定した。SLEDAI score>6を活動性SLEとした。3.ヒト内在性レ トロウイルスclone4-1のenv領域から合成ペプチド(p15E)を作製し、健常人PBMCに添 加培養し、各種サイトカイン産生を検討した。〔結果〕1. 組換えgp120を添加したPBMC において、リンパ球は活性化され、IL-2産生の低下等のSLE類似のリンパ球を呈した。2. 健常人に比してSLE患者血清中の MCP-1值、IL-16值は高く、RANTES值は低かった。 HIV 感染症での病態憎悪におけるケモカイン変動と、SLEでのそれとが類似していた。 IL-16值はSLE疾患活動性と相関した。3.組換えp15Eを添加したPBMCにおいて、IL-16、 MCP-1産生の上昇を認めた。〔結語】HIV研究で判明した現象の一部は、SLEの病態と 類似性があり、SLEで認められる免疫異常の解明に応用できると考えられる。

\section{W 16-4}

エストロゲン誘導遺伝子産物の免疫応答への影響

○小池竜司、山田寛子、飯塚利彦、宮坂信之 (東京医科歯科大学・第一内科)

[目的]SLEを初めとする自己免疫疾患発病や免疫応答の強さには明らかに性差が存在するた め、そのメカニズムを代表的女性ホルモンであるエストロゲンによって発現誘導される遺伝子を 検索し、その解析を通じて検討する。[方法］RAP Differential Display法により免疫系細胞にエ ストロゲン添加によって発現量が増加する遺伝子を検索した。得られた遺伝子断片をクローニン グしたところ、抗HCV抗体に対する交差反応性が報告されているチンパンジーGOR遺伝子のヒト ホモログであった。そこでこの遺伝子産物の自己抗原性や免疫応答への影響を検討し、エストロ ゲン自体の作用について考察する。[結果] GOR遺伝子ヒトホモログはチンパンジーと高度の相 同性を示すにもかかわらずHCVとの交差性が予想される領域は翻訳されず、自己抗原としての意 義は薄いと考えられた。いっぽうGOR遺伝子産物は細胞内では核に局在し、その強制発現によっ て細胞の增殖や生存に影響は認められなかったが、炎症性サイトカインによるケモカイン産生応 答を抑制するのが認められた。［結語］これまで報告されている事実と合わせて考えると、少な くとも in vitroでは、エストロゲンおよびその下流の遺伝子産物は単独では炎症反応や免疫応答に 対しては抑制的に作用することが示唆された。生体での免疫応答に対する影響を調べる上では、 その作用機序を深く理解し、他の分子の関与も含めて検討を行う必要がある。 


\section{W 16-5}

慢性関節リウマチ(RA)の病態形成におけるオピオイドペプチドの役割

\section{○武半優子}

(聖マリアンナ医大・免疫学病害動物学)

【目的】慢性関節リウマチ(RA)の病態は、神経・内分泌・免疫系により影響される。神 経ペプチドのひとつであるオピオイドペプチドがRA滑膜細胞機能におよほす影響を明らか にし、さらに関節局所におけるオピオイドペブチドの産生とその受容体の発現を検討した。

【方法】オピオイドペプチドである $\beta$ エンドルフィン、メチオニンエンケファリン、ロイシ ンエンケファリンについて検討した。RA患者の滑膜組織から滑膜細胞を単離し、この滑膜 細胞によるサイトカイン産生、メタロプロテナーゼ（MMP）産生に対するオピオイドペプチ ドの作用を観察した。滑膜組織におけるオピオピオイドペプチドの産生とオピオイドレセプ ターの発現を免疫組織染色で検討した。

【結果】オビオイドペプチドは滑膜細胞からの増殖反応、TNF- $\alpha$ 、IL-1 $\beta$ 産生、MMP-9産 生を抑制した。さらにオピオイドペプチドは滑膜細胞や滑膜浸潤リンパ球が産生し、オピオ イドレセプターはマクロファージ様滑膜細胞に発現していた。

【結語】オピオイドペプチドはRA滑膜細胞が産生し、滑膜表層部のマクロファージ様滑膜 細胞上のレセプターを介して、オートクラインあるいはパラクラインの様式でRA炎症の鎮 静化に作用する。

[共同演者 鈴木登、坂根剛（聖マリアンナ医科大学）、金子敦史、浅井富明(国立名古屋病院・整形外科)]

\section{W 16-6}

SLEの病態に及ぼす紫外線の作用

○船坂陽子

（神戸大学医学部・皮膚科）

SLEの皮渗は日光裸露部に多く、また半数近くの患者で光線過敏があると報告されてお り、SLEの病態形成への紫外線の関与が推察されてきた。このことは、中波長紫外線(UVB, 280-320nm)および長波長紫外線(UVA，320-400nm)照射にて、臨床的および病理組織学的に SLE に合致する皮疹が誘発し得たことより確認された。紫外線のSLE 患者皮䖉への作用 機序として、1）UVB は表皮ケラチノサイト(KC)での SSA/Ro、SSB/La、U1-RNP 抗原の 細胞表面への移行をえ進させ、 $\mathrm{KC}$ 上での抗原抗体反応を増強、2) 血管内皮細胞の E-selectin 発現の元進、3）Ro 抗体含有血清存在下、紫外線による血管拡張の增強、4）紫外線誘導 免疫細胞のサイトカインによる組織障害、等が報告されてきた。紫外線暴露後、皮膚以外 の症状悪化がみられることも知られており、変性 DNA が KC より放出されて末梢循環に 入り、DNA-抗 DNA 抗体の免度複合体が循環する、あるいは紫外線照射 DNA はより強い 免疫原性をもつ、等の機序が考えられている。従って、SLEの病状悪化の予防には、紫外 線に対する防御が不可欠と考えられる。紫外線に対する皮膚の異常反応は、紅斑形成の感 受性元進ではなく、むしろ紅斑が遷延することが特徵である。紫外線量を考慮した、日常 生活における具体的な防御法について、サンスクリーンの使用法等を交えて概説する。 


\section{W 16-7}

閦原病における酸化ストレスの関与 : チオレドキシン/ ADFからの検討

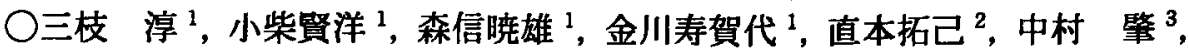
淀井淳司 ${ }^{3}$, 能谷俊一 1

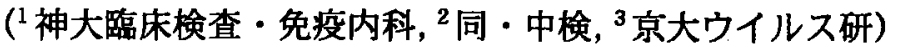

【目的】自己免疫疾患の病因は不明であるが、特定の遺伝素因を有するヒトに何らかの 環境因子が作用して発症すると考えられている。今回翏原病の病因病態の解明を目的とし て、遺伝素因として抗酸化機構に関与する遺伝子の多型性を検討し、また環境因子として の酸化ストレスの関与についてチオレドキシン(TRX)/Adult T cell derived factor(ADF) を中心に検討した。【方法】(1)血䑲、関節液の TRX/ADF 濃度は高感度 ELISA で測定し た。(2)末梢血白血球より DNA を抽出し、PCR 法を用い GSTM1/GSTT1 遺伝子多型性を 調ベた。(3)ヒト培養ケラチノサイト紐胞株(HaCaT)を用いて、紫外線(UVB)照射及び酸化 版である diamide の添加培養後の SS-A/Ro 抗原の細胞表面への発現を間接蛍光抗体法 にて解析し、培盖上清中の TRX/ADF 濃度も測定した。【結果】(1)RA、SLE、及びシェ 一グレン症候群患者の血漿 TRX/ADF 浱度は正常人に比し有意に高く、RA 患者関節液中 の TRX/ADF 謈度は OA 患者の数倍高かった。(2)シェーグレン症候群では、GSTM1 null の症例が有意に多く、SLE では GSTM1 null.GSTM1 GSTT1 null 両者久損の double null の症例が有意に多かった。(3)紫外線(UVB)照射及び diamide の添加培養後にケラチノサ イト細胞株表面への SS-A/Ro の発現を認めた。また刺激後の培盖上清中の TRX/ADF 濃度の上昇も認めた。【結語】擢原病の病因病態に酸化ストレスの関与が示唆された。

\section{W 16-8}

マウスSLEモデルにおける環境因子と遺伝因子の相互作用

○佐藤 実、吉田秀雄

（フロリダ大学医学部内科リウマチ臨床免疫部門）

目的：免疫系に影響する $l p r, g l d, x i d$ 遺伝子と環境因子(プリスタン、鉱物油、塩化水 銀、LPS）の、マウスSLE表現型への影響を追求する。方法：正常マウス(BALB/c,B6, CBA,SJL/J)、xid(x-linked immunodeficiency)、SLEマウス(NZB/W F1, MRL/lpr, $\mathrm{MRL}+/+, \mathrm{B} 6 / l p r, \mathrm{~B} 6 / \mathrm{gld})$ にプリスタンまたはPBSを投与し自己抗体、サイトカイン産生 を調へた。結果：SJL/Jマウスは塩化水銀投与で抗fibrillarin抗体を産生したが、プリスタ ンはリボソームP抗体( $\mathrm{r}-\mathrm{P})$ を誘導した。lpr, gldはB6マウスに、高力価の抗クロマチン /DNA抗体のみを誘導したが、プリスタンは抗 Sm、r-P抗体を誘導した。MRL/lpr, B 6/lpr, B 6/gld マウスはプリスタン投与で増悪せず自己抗体も変化しなかった。Btk変異 $\mathrm{id}$ は CBA アウスに抗RNA helicase A(RHA)抗体を誘導したが、プリスタンは抗nRNP/Sm, Su抗体を誘導した。プリスタンはNZB/W F1 マウスの抗RHA抗体を抑制する一方抗Sm,Su 抗体を誘導した。抗n RNP/Sm, Su抗体はIFN-g//LL-12、抗クロマチン/DNA抗体はIL-6、 抗RHA抗体はIL-4/IL-6産生と関連した。プリスタンはlpr,gld以外の遺伝因子によるマウ スSLEを增悪させるのに加え、サイトカインバランスをTh1に移行させ、自己抗体の特異 性を変化させた。結語 : 同一背景遺伝子を持つマウスでも、異なった環境因子、遺伝因子 はサイトカインバランスの変化とともに、全く異なる自己抗体を誘導する。 


\section{W 17-1}

候補遺伝子アブローチによる自己免疫疾患感受性遺伝子の解析 ○土屋尚之、徳永勝士

(東大・医・人類遺伝)

われわれはSLE，RA，Crohn病を主な対象として、(1)病態上の重要性、(2) 位置的情報、(3)炎症局所における発現 profile 等に基づく候補遺伝子の設定 と変異解析により、感受性遺伝子の検出を目指している。(1)、(2)のアプロー チとして、これまでにCD28, CTLA-4, CD80, CD86, CD22, TNFR2, CCR3, CCR4, CXCR1, CXCR2, CXCR3, SHP-1などの免疫系機能分子の変異解析を終了し、 これらのほとんどにおいて新たな多型を見いだした。関連解析の結果、SLE と TNFR2-196R、FcyR3B-NA2 との関連を新たに報告し、また、Crohn 病に おいて HLA-DRB1 と TNF $\alpha$ promoter 上流領域多型がそれぞれ独立に疾患に 関連することを見出した。一方、(3)のアプローチのための基礎的検討として、 differential display 法を用いてRA 滑膜やCrohn 病腸管病変部において優先 的に発現する遺伝子群を検討し、それぞれID family genes, FLIPなど、病態 に関与する可能性を強く持つ複数の遺伝子を検出した。今後これらの遺伝子 についての変異解析も進める予定である。今回の発表では、以上のような一 連の研究のこれまでの成果を総括的に議論する。

\section{W 17-2}

SLEの遺伝要因 : T細胞活性化・アポトーシスに関連する遺伝子を中心に

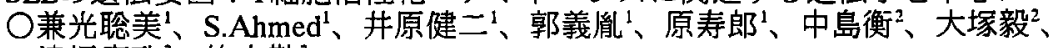
津坂憲政 ${ }^{3} 、$ 竹内勤 ${ }^{3}$

( ${ }^{1}$ 九州大学大学院医学系研究科小児科、 ${ }^{2}$ 同第一内科、䛴玉医科大学

総合医療センター第二内科)

[目的］SLEの病態形成には自己反応性リンパ球の排除障害が存在し、その機序にはリンパ球の 活性化やアポトーシスの障害によるトレランスの破綻が考えられる。Fasはアポトーシスのシグ ナル伝達に関する膜蛋白でSLEにおいても樣々な検討がなされているが、その役割は不明である。 CD28、CTLA-4はT細胞シグナルの補助刺激分子で、それそれ活性化と抑制の刺激を伝え、その バランスを保つことで自己免疫との関与が考えられている。今回私たちは、Fas promoter領域の 遺伝子多型とCTLA-4及びCD28遺伝子の多型を用いてSLEにおける役割を検討した。

[方法] SLE113症例において、Fas遺伝子のpromoter領域の多型に関しては、-1377G/Aと-670A/G の二力所の遺伝子多型を、またCTLA-4遺伝子のpromoter領域の-31C/T、exon1の49G/Aどexon4の 3'UTR(AT)n多型を、CD28遺伝子に関してはintron3の+17T/Cの多型をallele-specificPCR、PCRSSCP、PCR-RFLP等を用いて検討した。

[結果］SLEにおいて、Fas promoter -670A/G遺伝子多型では、A alleleを持つ頻度 $(\mathrm{P}=0.02)$ が、 CTLA-4 49A/G遺伝子多型では、 $\mathrm{G}$ alleleを持つ頻度( $\mathrm{P}=0.003)$ が、また3'UTR(AT)n多型では104bp $(\mathrm{P}=0.02)$ 、 $106 \mathrm{bp}$ allele $(\mathrm{P}=0.008)$ を持つ頻度がコントロールに比して有意に高かった。その他の 多型の検討では有意差は認めなかった。

[結語] 今回の結果より、Fas promoter遺伝子の-670A/G多型及びCTLA-4 遺伝子exon $1049 \mathrm{G} / \mathrm{A}$ と exon4の3'UTR(AT)nの多型はSLEの病態形成に関与する可能性が考えられた。しかし、Fas及び CTLA-4の多型間によるシグナル伝達に関しては今後も検討が必要である。 
W 17-3

\author{
SLEの素因遺伝子 \\ ○広瀨幸子 \\ （順天堂大·医・第二病理）
}

〔目的〕SLEは多遺伝子疾患で、加算効果や相補効果を示す感受性遺伝子とこれらを修 飾する多数の遺伝子が複雑に関与する。さらにヒト遺伝子の高度な多様性が加わり、ヒト SLE遺伝子解析にはかなりの難点がある。我々はSLE自然発症系であるNZB/W F1モデル マウスを利用してゲノムワイドな遺伝的解析により、SLE遺伝子の同定を試みた。

〔方法〕 F1 x NZW退交配マウス約250匹のSLE病態についてのmicrosatellite DNA多型 に基づく量的形質遺伝子解析を行い、SLE遺伝子の遺伝子座の決定により候補遺伝子を推 定した。

〔結果〕SLEに特徵的な高免疫グロブリン血症を伴うB細胞の異常活性化には、主に第 1 および第 4 染色体上の遺伝子が関与してた。前者はB 細胞活性化を抑制する分子F $\gamma$ RIIB 1 をコードする遺伝子の制御領域多型によるものであり、高IgG血症の感受性遺伝子と考えら れた。後者はTNF receptor 遺伝子群に連鎖しており、高IgM血症の感受性遺伝子と考元ら れた。

〔結語〕上記の遺伝子領域がヒトでも関与している事実が示されてきている。感受性遺伝 子は免疫機能分子の構造多型よりはむしろ制御領域多型によると考えられ、モデル系での研 究成果はヒトSLE遺伝子解析に先立つ重要な礎となる。

\title{
W 17-4
}

\author{
膠原病の遉伝要因 : MRL/lpr モデルマウスのトータルゲノム解析 \\ 能勢真人 \\ （愛媛大・医学部 $\cdot$ 第二病理）
}

\begin{abstract}
膠原病に包括される各疾患の病態・病理像は多彩であり、また、相互の類似性や重複性 も認められるところから、診断、治療上の問題点も多い。これらの多様性、類似性の起源 をゲノムに求め、種々の膠原病の病態・病理像を自然発症する $\mathrm{MRL} / \mathrm{MpJ}-\mathrm{lpr} / \mathrm{lpr}$ (MRL/lpr) マウスをモデルとして、そのトータルゲノムの解析を行った。いずれの膠原病も発症しな い C3H/HeJ-lpr/lpr マウスとの交配系（N2, F2 世代）を用いて、個々の病像を支配する遺伝 子座をマップした結果、1) 糸球体腎炎、関節炎、血管炎、睡液腺炎は、複数の疾患感受 性遺伝子の互いに異なった組み合わせによって発症すること、2）これらの遺伝子間には、 相加性、階層性が存在すること、3）少なくとも腎炎、血管炎の発症に共通した遺伝子が 存在すること、4）血管炎の臓器特異性を規定する遺伝子が存在すること、5）環境要因 によりこれらの病像の選択的抑制が生ずること、を明らかにした。また、位置的候補遺伝 子探索の結果、オステオポンティン、CD72 が機能的差異を生み出す遺伝子多型を有する ことを明らかにした。それ故、膠原病の発症は、Mather の提唱したポリジーン遺伝の概念 で把握し得ること、各病像の多様性、類似性は、ポリジーンの種々の組み合わせに規定さ れること、また、そのポリジーンの少なくともいくつかは遺伝子多型そのものであること が明らかとなった。
\end{abstract}




\section{W 17-5}

慢性関節リウマチの疾患感受性遺伝子の研究

$\mathrm{O}^{1}$ 塩沢俊一, ${ }^{1}$ 駒井浩一郎, ${ }^{1}$ 小西良武, ${ }^{1}$ 向江直子, ${ }^{1}$ 日笠真理, ${ }^{2}$ 塩沢和子,

2 居村茂明（ ${ }^{1}$ 神戸大学医学部保健学科, ${ }^{2}$ 国立加古川病院）

【目的】私どもは慢性関節リウマチの遺伝素因について, マイクロサテライトマーカー解 析を行い第 1 染色体 D1S214/253, 第 8 染色体 D8S556, X 染色体 DXS1232 の 3 筒所に $\mathrm{RA}$ の疾患遺伝子座位を特定し，候補遺伝子を $R A 1, R A 2, R A 3$ と呼んだ。この中で，RA1

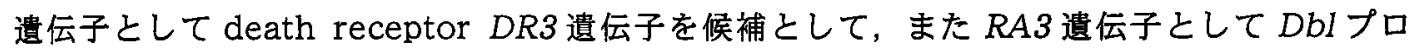
トオンコジーンの欠損変位を同定した。

【方法】疾患遺伝子の解析は radiation hybrid mappingによる物理的地図を作成した後, CDNA および DNA レベルのクロモソームウォークにより行った。

【結果】マイクロサテライトマーカーによる再解析と G3 radiation hybrid 法により, DXS 1232 の近傍 DXS984に単独頂值域を見出し, 同部位に $D b 1$ 遺伝子を特定し, $R A 3$ が $D b 1$ 遺伝子 3 端近くの $223 \mathrm{bp}$ のエキソンスキッピング変異であり，この基盤に DNA 上の $\mathrm{nt} 2522+394(\mathrm{C} \rightarrow \mathrm{T})$ 等の SNP を見出した。Dbl は G 蛋白をコードし, Rac, cdc42, rho を へて NADPH オキシダーゼおよび白血球機能に影響を及ぼすことから，好中球の活性酸素 生成能を㭘定すると $D b l$ 変異例で特異的に fMLP 刺激による活性酸素生成が低下していた。 RA1 については定量 RT-PCR にて DR3 の膜貫通細胞外領域が細胞内 death domain の倍 量存在し，患者ではカスペース 8 の分解が低下し，細胞死シグナル伝達が障害されていた。 